\title{
GROWTH OPPORTUNITY DALAM MEMODERASI PENGARUH LEVERAGE DAN DEBT MATURITY TERHADAP KEPUTUSAN INVESTASI
}

\author{
Oleh: \\ Loecita Sandiar \\ Dosen Prodi Pendidikan Ekonomi \\ Fakultas Ilmu Pendidikan dan Pengetahuan Sosial \\ Universitas Indraprasta PGRI \\ Email: \\ loecitasandiar@gmail.com
}

\begin{abstract}
ABSTRAK
Penelitian ini bertujuan untuk menguji pengaruh leverage terhadap keputusan investasi, debt maturity terhadap keputusan investasi, growth opportunities terhadap keputusan investasi, leverage terhadap keputusan investasi yang dimoderasi oleh growth opportunities, dan debt maturity terhadap keputusan investasi yang dimoderasi oleh growth opportunities. Penelitian ini difokuskan pada perusahaan yang telah go public dan terdaftar di Bursa Efek Indonesia untuk periode 2006 - 2010. Metode pengambilan sampel yang digunakan adalah purposive sampling dan sampel sebanyak 45 perusahaan. Metode pengolahan statistik menggunakan uji signifikansi fixed effect, uji hausman dan regresi data panel. Pada penelitan ini ditemukan bahwa leverage berpengaruh negatif terhadap keputusan investasi, debt maturity berpengaruh negatif terhadap keputusan investasi, growth opportunities berpengaruh positif terhadap keputusan investasi, tidak ada interaksi antara leverage dan growth opportunities dalam mempengaruhi keputusan investasi, dan growth opportunities mampu memoderasi pengaruh debt maturity terhadap keputusan investasi.
\end{abstract}

Kata kunci: leverage, debt maturity, growth opportunity, keputusan investasi 


\section{A. PENDAHULUAN}

Investasi adalah kegiatan ekonomi yang penting dalam pengelolaan keuangan perusahaan. Perusahaan memutuskan untuk berinvestasi karena mengharapkan manfaat yang diperoleh di masa yang akan datang, seperti peningkatan produksi barang dan jasa, perluasan pangsa pasar, perolehan profit dan sebagainya. Myers et al (2001), keputusan investasi adalah keputusan untuk berinvestasi pada aktiva riil seperti peralatan, tanah dan keterampilan (know-how). Keputusan investasi yang kurang dapat menyebabkan perencanaan mengalami kegagalan. Kegagalan tersebut berupa penurunan kinerja atau penurunan nilai pasar perusahaan.

Menurut Myers dalam Lestari (2004), perusahaan yang memiliki tingkat pertumbuhan yang lebih tinggi lebih cenderung untuk tidak menambah hutang karena masalah underinvestment dan asset substitution. Lang et al (1996) menemukan bahwa leverage dapat mencegah investasi pada perusahaan dengan investment opportunities rendah dan mengemukakan bahwa leverage yang tinggi akan membatasi manajer untuk melakukan kebijakan investasi dengan menghamburkan free cash flow yang ada.

Perusahaan dengan tingkat leverage yang tinggi akan kurang menyukai memanfaatkan growth opportunities yang bernilai jika dibandingkan dengan perusahaan yang memiliki tingkat leverage yang rendah, dimana teori underinvestment lebih memusatkan perhatian pada efek likuiditas, perusahaan dengan tanggung jawab hutang yang besar akan memiliki investasi yang kurang (Aivazian et al.2005).

Aivazian et al. (2005) menemukan bahwa leverage memiliki efek negatif pada investasi, mendukung hipotesis bahwa leverage memiliki peran penting bagi perusahaan dengan growth opportunities yang rendah. Dalam makalah yang terkait (Aivazian et al., 2005), menunjukkan bahwa setelah mengendalikan leverage, maturitas hutang (debt maturity) juga memiliki dampak negatif terhadap keputusan investasi. Penelitian ini juga meneliti hubungan antara pembiayaan dan keputusan setelah investasi. Penelitian Johnson (2003) dan Billett et al. (2007) menunjukkan perusahaan dengan pertumbuhan tinggi mengadopsi leverage rendah dan kebijakan debt maturity untuk mengontrol masalah keagenan.

Leverage dapat berpengaruh negatif terhadap keputusan investasi, karena biaya keagenan hutang yang tidak dapat sepenuhnya dikurangi. Temuan tersebut juga konsisten dengan hipotesis tentang peran leverage perusahaan dengan growth opportunities yang rendah. Debt maturity tidak memiliki efek negatif langsung terhadap keputusan investasi. Perusahaan dengan debt maturity lebih tinggi akan mampu mengambil growth opportunities lebih tinggi dan membuat lebih banyak investasi (Dang, 2011).

Ketika perusahaan memilih hutang sebagai sumber pendanaan, makaperusahaan harus mempertimbangkan kebijakan-kebijakan financial yang lain, misalnya: debt maturity, priority, apakah menggunakan public debt ataukah private debt. Ketika perusahaan memilih hutang sebagai sumber pendanaan, maka perusahaan perlu mempertimbangkan maturitas hutang (debt maturity). Hal ini dikarenakan pemilihan maturitas hutang (debt maturity) akan mempengaruhi nilai perusahaan (Megginson, 1997). 
Penentuan kebijakan hutang dan kebijakan maturitas hutang harus dipertimbangkan secara bersama-sama (simultan). Berdasarkan kerangka pemikiran Barclay, et.al. (2001), maka penelitian ini bertujuan untuk:

1. Menguji pengaruh leverage terhadap keputusan investasi.

2. Menguji pengaruh debt maturity terhadap keputusan investasi.

3. Menguji pengaruh growth opportunities terhadap keputusan investasi.

4. Menguji pengaruh leverage terhadap keputusan investasi yang dimoderasi oleh growth opportunities.

5. Menguji pengaruh debt maturity terhadap keputusan investasi yang dimoderasi oleh growth opportunities.

\section{B. KAJIAN PUSTAKA}

\section{Leverage dan Investasi}

Pengujian yang dilakukan oleh McConnell dan Servaes (1995) serta Lang et al (1996) memperlihatkan bahwa leverage mempunyai pengaruh yang negatif dan signifikan pada investasi perusahaan di Amerika Serikat. Begitu pula dengan penelitian yang dilakukan oleh Aivazian, et al (2005) menemukan bahwa leverage berpengaruh negatif terhadap investasi pada perusahaan-perusahaan di Canada. Myers (1977), Jensen (1986), dan Stulz (1990) memprediksi bahwa leverage memiliki dampak penting pada kebijakan investasi. Dalam model Myers (1977), hutang dapat menciptakan sebuah efek overhang, di mana perusahaan dapat menemukan kesulitan untuk mendanai proyek-proyek baru karena hasil dari proyek-proyek tersebut untuk membayar hutang lama.

Kebijakan hutang sebagai sumber pendanaan perusahaan berpotensi menyebabkan konflik keagenan antara pemegang saham dan pemegang obligasi yang juga menyebabkan biaya keagenan (Jensen dan Meckling, 1976). Kondisi ini menunjukkan penggunaan hutang pada perusahaan yang memiliki kesempatan investasi yang tinggi, akan menjadi mahal dan menyebabkan tingginya biaya hutang. Untuk menghindari masalah biaya hutang, perusahaan-perusahaan dengan kesempatan investasi yang tinggi akan memilih untuk menggunakan pinjaman dalam jumlah kecil atau menggunakan dana internal sebagai alternatif pendanaan. Akhirnya, korelasi antara leverage dan peluang investasi akan negatif.

$\mathrm{H}_{1}$ : Leverage berpengaruh negatif terhadap keputusan investasi.

\section{Debt Maturity dan Investasi}

Debt maturity dapat mempengaruhi investasi perusahaan, Myers (1977) menganalisis eksternalitas yang mungkin dihasilkan oleh hutang pada pemegang saham dan manajemen strategi investasi yang optimal. Perusahaan dengan hutang jangka panjang akan mampu untuk memanfaatkan peluang pertumbuhan, dibandingkan perusahaan dengan hutang jangka pendek. Berdasarkan uraian tersebut dapat dirumuskan hipotesis penelitian ini adalah:

$\mathrm{H}_{2}$ : Debt maturity berpengaruh negatif terhadap keputusan investasi. 


\section{Growth Opportunities dan Investasi}

Perusahaan dengan growth opportunities tinggi cenderung melakukan investasi untuk mendukung pertumbuhannya. Investasi perusahaan berhubungan dengan pendanaan perusahaan. Semakin besar kesempatan investasi akan semakin besar kemungkinan perusahaan menggunakan sumber dana eksternal khususnya hutang apabila internal equity dari retained earning (laba ditahan) tidak mencukupi.

$\mathrm{H}_{3}$ : Growth opportunities berpengaruh positif terhadap keputusan investasi.

\section{Leverage, Growth Opportunities dan Investasi}

Myers (1977) dan Lestari (2004), mengemukakan bahwa perusahaan yang memiliki growth opportunities yang baik cenderung memperkecil tingkat leverage-nya. Berkaitan dengan masalah underinvestment dan asset substitution. Berkaitan dengan masalah underinvestment, manajer cenderung tidak melakukan investasi pada proyek yang memiliki NPV positif. Masalah asset substitution, peningkatan hutang berarti sebagian aktiva perusahaan akan dijadikan sebagai jaminan atas hutang tersebut.

Manajemen memutuskan menggunakan leverage didasarkan pada informasi pribadinya mengenai growth perusahaan kedepannya. Manajer dari perusahaan yang memiliki high growth opportunity akan memilih mengurangi leverage dikarenakan perusahaan tidak dapat mengambil keuntungan dari investment opportunity yang dimiliknya jika mereka harus meningkatkan pendanaan dari luar perusahaan (Lang et al. 1996). Berdasarkan uraian tersebut dapat dirumuskan hipotesis penelitian ini adalah:

$\mathrm{H}_{4}$ : Pengaruh negatif leverage terhadap keputusan investasi lebih kecil pada perusahaan yang memiliki growth opportunities tinggi.

\section{Debt Maturity, Growth Opportunities dan Investasi}

Hipotesis underinvestment Myers (1977) memberikan implikasi empiris untuk keterkaitan antara leverage, debt maturity, dan investasi. Penurunan tingkat leverage atau memperpendek debt maturity disebabkan oleh debt overhang berisiko. Leverage dan debt maturity yang rendah merupakan pilihan pertumbuhan yang harus diambil, sehingga tingkat investasi menjadi tinggi. Berdasarkan uraian tersebut dapat dirumuskan hipotesis penelitian ini adalah:

$\mathrm{H}_{5}$ : Pengaruh negatif debt maturity terhadap keputusan investasi lebih kecil pada perusahaan yang memiliki growth opportunities tinggi.

\section{METODE PENELITIAN}

\section{Data dan Sampel}

Data yang digunakan dalam penelitian ini adalah data sekunder yang diperoleh dari laporan keuangan perusahaan yang telah diterbitkan dan dipublikasikan dari situs www.bei.co.id. Data yang diperlukan meliputi: jumlah aset, penjualan, jumlah ekuitas, jumlah saham beredar, total hutang, total hutang jangka panjang, dan Price-to-Book-Value. Metode pengambilan sampel yang 
digunakan adalah purposive sampling dengan kriteria sebagai berikut: perusahaan manufaktur yang listing di Bursa Efek Indonesia. Sampel yang digunakan sebanyak 45 perusahaan dengan kurun waktu 2006-2010.

\section{Pengukuran Variabel}

\section{a. Variabel dependen}

Variabel dependen dalam penelitian ini adalah keputusan investasi. Proksi investasi yang digunakan mengacu pada proksi yang digunakan Aivazian et al. (2005).

Investment $=$ Net Investment/(Fix asset ${ }_{t}-$ Fix asset $\left.{ }_{t-1}\right)$

b. Variabel independen

Variabel independen dalam penelitian ini adalah leverage dan debt maturity. Proksi leverage mengacu pada penelitian Aivazian et al. (2005). Sedangkan proksi debt maturity mengacu pada penelitian Dang (2011).

(a) Leverage $=$ Total Debt/Total Asset

(b) Debt Maturity = Long term debt/Total Debt

\section{c. Variabel moderating}

Variabel moderating dalam penelitian ini adalah growth opportunities. Untuk menghitung growth opportunities menggunakan proksi Tobin's Q. Proksi Tobin's Q yang digunakan diambil dari penelitian Aivazian, et al. (2005), didefiniskan sebagai berikut:

Total liabilities + Market value of common stock + estimated market value of preferred stock

Tobin's $\mathrm{Q}=$

Book value of total assets

\section{Model Pengujian Hipotesis}

Uji hipotesis dilakukan dengan menggunakan teknik regresi data panel pada regresi kuadrat terkecil sederhana (Ordinary Least Square / OLS ), yakni dengan menggunakan investment sebagai variabel dependen dan leverage dan debt maturity sebagai variabel independen, sedangkan growth opportunities sebagai variabel moderating. Mengacu pada penelitian Dang (2011).

Adapun hipotesis yang diuji mempunyai persamaan sebagai berikut:

INV $=\mathrm{a}_{0}+\mathrm{a}_{1} \mathrm{LEV}+\mathrm{a}_{2}$ MAT $+\mathrm{a}_{3}$ GROWTH $\varepsilon_{i} \quad\left(\mathrm{H}_{1}-\mathrm{H}_{3}\right)$

INV $=\mathrm{a}_{0}+\mathrm{a}_{1}$ LEV $+\mathrm{a}_{2}$ GROWTH $+\mathrm{a}_{3} \mathrm{LEV}^{*}$ GROWTH $+\varepsilon_{i} \quad\left(\mathrm{H}_{4}\right)$

INV $=\mathrm{a}_{0}+\mathrm{a}_{1}$ MAT $+\mathrm{a}_{2}$ GROWTH $+\mathrm{a}_{3}$ MAT $^{*}$ GROWTH $+\varepsilon_{i}\left(\mathrm{H}_{5}\right)$

\section{HASIL DAN PEMBAHASAN}

\section{Statistik Deskriptif}

Deskripsi variabel penelitian bertujuan untuk mengetahui gambaran masingmasing variabel penelitian yang disajikan dengan statistik deskriptif. Berdasarkan desain penelitian maka sumber informasi yang diperoleh dideskripsikan dalam bentuk nilai maksimum, nilai minimum, rata-rata, dan standar deviasi. 
Tabel 1.

Statistik Deskriptif Variabel Penelitian

\begin{tabular}{lcccc}
\hline \multicolumn{1}{c}{ VARIABEL } & MINIMUM & MAXIMUM & MEAN & STD. $\boldsymbol{D E} \boldsymbol{V}$ \\
\hline Keputusan Investasi & $-130,441$ & 61,843 & 0,759 & 11,585 \\
Leverage & 0,124 & 1,072 & 0,558 & 0,200 \\
Debt Maturity & 0,021 & 0,997 & 0,328 & 0,235 \\
Growth & 0,444 & 4,929 & 1,125 & 0,601 \\
\hline
\end{tabular}

Tidak semua perusahaan mempunyai keputusan investasi yang positif. Berdasarkan Tabel di atas rata-rata keputusan investasi perusahaan sampel selama periode 2006-2010 adalah sebesar 0,759 dengan standar deviasi sebesar 11,585. Nilai keputusan investasi paling rendah yaitu sebesar -130,441, sedangkan nilai investasi yang paling tinggi yaitu sebesar 61,843 .

Variabel leverage memiliki rentang nilai dari 0,124 hingga 1,072. Ratarata leverage sebesar 0,558 dan standar deviasinya bernilai 0,200. Variabel debt maturity memiliki nilai terendah sebesar 0,021 dan nilai tertinggi 0,997 . Rata-rata debt maturity sebesar 0,328 dan standar deviasinya bernilai 0,235. Nilai variabel growth antara 0,444 sampai dengan 4,929 dengan rata-rata sebesar 1,125 dan standar deviasi sebesar 0,601.

\section{Pengujian Hipotesis Pertama, Kedua dan Ketiga}

Rumusan hipotesis pertama yang diuji dalam penelitian ini adalah: leverage berpengaruh negatif terhadap keputusan investasi. Hipotesis kedua adalah debt maturity berpengaruh negatif terhadap keputusan investasi dan hipotesis ketiga adalah growth opportunities berpengaruh positif terhadap keputusan investasi. Kriteria penerimaan hipotesis diterima apabila nilai signifikansi $<0,05$. Pengujian hipotesis dilakukan dengan analisis regresi data panel. Hasil estimasi regresi data panel disajikan dalam Tabel 2 berikut:

Tabel 2.

Hasil Estimasi Regresi Hipotesis Pertama, Kedua dan Ketiga

\begin{tabular}{ccccc}
\hline VARIABEL & KOEFISIEN & T-STATISTIC & SIG. & $\begin{array}{c}\text { ADJUSTED } \\
\text { R-SQUARED }\end{array}$ \\
\hline C & 1,746 & 0,271 & 0,787 & \\
LEV & $-24,496$ & $-2,386$ & 0,018 & 0,113 \\
MAT & 14,905 & 2,135 & 0,034 & \\
GROWTH & 6,906 & 3,352 & 0,001 & \\
\hline
\end{tabular}

Dari Tabel 2 dapat diketahui bahwa untuk variabel leverage diperoleh nilai t hitung sebesar -2,386 dengan signifikansi 0,018. Oleh karena signifikansi kurang dari 0,05 ( $\operatorname{sig}<0,05)$ maka hipotesis yang menyatakan "leverage berpengaruh negatif terhadap keputusan investasi" diterima. Koefisien regresinya sebesar 24,496 memiliki arah negatif artinya semakin tinggi leverage maka semakin rendah keputusan investasinya. 
Variabel debt maturity diperoleh nilai t hitung sebesar 2,135 dengan signifikansi 0,034. Oleh karena signifikansi kurang dari 0,05 (sig < 0,05) maka hipotesis yang menyatakan "debt maturity berpengaruh terhadap keputusan investasi" diterima. Untuk variabel growth opportunities diperoleh nilai t hitung sebesar 3,352 dengan signifikansi 0,001. Oleh karena signifikansi kurang dari 0,05 (sig < 0,05) maka hipotesis yang menyatakan "growth opportunities berpengaruh positif terhadap keputusan investasi" diterima. Koefisien regresi sebesar 6,906 memiliki arah positif artinya semakin tinggi growth opportunities maka semakin tinggi keputusan investasinya.

Nilai Adjusted R-square sebesar 0,113 menunjukkan bahwa leverage, debt maturity dan growth opportunities secara bersama-sama memiliki kontribusi pengaruh terhadap keputusan investasi sebesar 11,3\%. Hal ini berarti bahwa keputusan investasi dipengaruhi oleh leverage, debt maturity dan growth opportunities sebesar $11,3 \%$ sedangkan sisanya dipengaruhi oleh faktor lain yang tidak diteliti dalam penelitian ini.

\section{Pengujian Hipotesis Keempat}

Pengujian pada hipotesis keempat ini bertujuan untuk melihat apakah pengaruh negatif leverage terhadap keputusan investasi lebih kecil pada perusahaan yang memiliki growth opportunities tinggi. Hasil estimasi regresi data panel untuk hipotesis keempat disajikan dalam Tabel berikut ini:

Tabel 3.

Hasil Estimasi Regresi Hipotesis Keempat

\begin{tabular}{ccccc}
\hline VARIABEL & KOEFISIEN & $\begin{array}{c}\text { T- } \\
\text { STATISTIC }\end{array}$ & SIG. & $\begin{array}{c}\text { ADJUSTED } \\
\boldsymbol{R} \text {-SQUARED }\end{array}$ \\
\hline C & $-0,494$ & $-0,062$ & 0,950 & \\
LEV & $-7,598$ & $-0,484$ & 0,629 & 0,098 \\
GROWTH & 11,241 & 2,698 & 0,008 & \\
LEVGROWTH & $-11,949$ & $-1,223$ & 0,223 & \\
\hline
\end{tabular}

Rumusan hipotesis yang diuji adalah pengaruh leverage terhadap keputusan investasi yang dimoderasi oleh growth opportunities. Dari Tabel 3 di atas dapat diketahui bahwa untuk variabel LEVGROWTH diperoleh nilai t hitung sebesar -1,223 dengan signifikansi 0,223. Oleh karena signifikansi lebih dari 0,05 (sig > 0,05) maka hipotesis yang menyatakan "pengaruh leverage terhadap keputusan investasi yang dimoderasi oleh growth opportunities" ditolak.

\section{Pengujian Hipotesis Kelima}

Pengujian pada hipotesis kelima ini bertujuan untuk melihat apakah pengaruh negatif debt maturity terhadap keputusan investasi lebih kecil pada perusahaan yang memiliki growth opportunities tinggi. Hasil estimasi regresi data panel untuk hipotesis kelima disajikan dalam Tabel berikut ini: 
Tabel 4.

Hasil Estimasi Regresi Hipotesis Kelima

\begin{tabular}{crrrc}
\hline \multirow{2}{*}{ VARIABEL } & \multirow{2}{*}{ KOEFISIEN } & \multicolumn{1}{c}{$\boldsymbol{T}$ - } & \multicolumn{1}{c}{ SIG. } & $\begin{array}{c}\text { ADJUSTED } \\
\text { STSATISTIC }\end{array}$ \\
\hline C & $-7,018$ & $-1,761$ & 0,079 & \\
MAT & $-1,770$ & $-0,176$ & 0,860 & 0,106 \\
GROWTH & 3,308 & 1,215 & 0,226 & \\
MATGROWTH & 12,155 & 2,053 & 0,041 & \\
\hline
\end{tabular}

Rumusan hipotesis yang diuji adalah pengaruh debt maturity terhadap keputusan investasi yang dimoderasi oleh growth opportunities. Dari Tabel 4 di atas dapat diketahui bahwa untuk variabel MATGROWTH diperoleh nilai t hitung sebesar 2,053 dengan signifikansi 0,041. Oleh karena signifikansi kurang dari 0,05 (sig < 0,05) maka hipotesis yang menyatakan "pengaruh debt maturity terhadap keputusan investasi yang dimoderasi oleh growth opportunities"diterima. Artinya growth opportunities memoderasi pengaruh debt maturity terhadap keputusan investasi.

\section{Pengaruh Leverage terhadap keputusan investasi}

Hasil penelitian ini mendukung penelitian sebelumnya yang dilakukan oleh McConnell dan Servaes (1995) serta Lang et al (1996) memperlihatkan bahwa leverage mempunyai pengaruh yang negatif dan signifikan pada investasi pada perusahaan di Amerika Serikat. Begitu pula dengan penelitian yang dilakukan oleh Aivazian, et al (2005) menemukan bahwa leverage berpengaruh negatif terhadap investasi pada perusahaan-perusahaan di Canada.

\section{Pengaruh Debt Maturity terhadap Keputusan Investasi}

Hasil penelitian menunjukkan debt maturity berpengaruh signifikan terhadap keputusan investasi. Penjelasan mengapa debt maturity berpengaruh negatif terhadap keputusan investasi telah diungkapkan oleh Myers (1977). Jika debt maturity setelah berakhirnya pilihan investasi perusahaan mengurangi insentif dari koalisi pemegang saham manajemen dalam pengendalian perusahaan untuk berinvestasi pada proyek dengan NPV positif, maka keuntungan bertambah kepada pemegang obligasi bukan pemegang saham. Oleh karena itu, perusahaan dengan hutang jangka panjang akan lebih mudah memanfaatkan peluang pertumbuhan dibandingkan perusahaan dengan debt maturity yang lebih pendek.

\section{Pengaruh Growth Opportunities terhadap Keputusan Investasi}

Growth opportunities terbukti berpengaruh positif terhadap keputusan investasi. Semakin tinggi growth opportunities maka semakin tinggi juga keputusan investasinya, begitupun sebaliknya. Sesuai dengan Myers (1977) tentang konsep mengenai investment opprtunity set (IOS). Perusahaan akan memiliki peluang untuk bertumbuh (growth opportunities) apabila investasi yang 
dipilih saat ini dapat memberikan keuntungan di masa depan. Hasil pengujian hipotesis ini mendukung penelitian yang dilakukan oleh Bestari (2005) yang menyatakan bahwa perusahaan yang bertumbuh memiliki nilai perusahaan yang lebih baik karena rasio debt to equity-nya lebih rendah dalam kebijakan struktur modalnya.

\section{Pengaruh Leverage terhadap Keputusan Investasi Lebih Kecil pada Perusahaan yang Memiliki Growth Opportunities Tinggi}

Manajemen memutuskan untuk menggunakan leverage didasarkan pada informasi pribadinya mengenai growth perusahaan kedepannya. Literatur dalam struktur modal yang telah ada mengemukakan bahwa manajer dari perusahaan yang memiliki high growth opportunities akan memilih mengurangi leverage dikarenakan perusahaan tersebut tidak dapat mengambil keuntungan dari investment opportunity yang dimilikinya jika mereka harus meningkatkan pendanaan dari luar perusahaan (Lang et al. 1996).

\section{Pengaruh Debt Maturity terhadap Keputusan Investasi Lebih Kecil pada Perusahaan yang Memiliki Growth Opportunities Tinggi}

Penelitian ini berhasil memberikan bukti empiris bahwa growth opportunities mampu memoderasi pengaruh debt maturity terhadap keputusan investasi. Hasil ini sesuai dengan hipotesis underinvestment Myers (1977) yang memberikan implikasi empiris tentang keterkaitan antara leverage, debt maturity, dan investasi. Penurunan tingkat leverage atau memperpendek debt maturity terhadap masalah underinvestment disebabkan oleh overhang utang berisiko.

\section{E. SIMPULAN}

Berdasarkan hasil penelitian dan pembahasan yang telah dilakukan, maka dapat disimpulkan sebagai berikut:

a. Pengujian hipotesis pertama, dengan menggunakan pendekatan fixed effect, terbukti bahwa leverage berpengaruh negatif terhadap keputusan investasi. Sejalan dengan teori underinvestment perusahaan dengan tanggung jawab hutang yang besar memiliki investasi yang kurang.

b. Pengujian hipotesis kedua, dengan menggunakan pendekatan fixed effect, terbukti bahwa debt maturity berpengaruh negatif terhadap keputusan investasi.

c. Pengujian hipotesis ketiga, dengan menggunakan pendekatan fixed effect, terbukti bahwa growth opportunities berpengaruh positif terhadap keputusan investasi. Artinya, semakin tinggi growth opportunities maka semakin tinggi juga keputusan investasinya, begitupun sebaliknya.

d. Pengujian hipotesis keempat, dengan menggunakan pendekatan fixed effect, diperoleh hasil bahwa growth opportunities dalam memoderasi pengaruh leverage terhadap keputusan investasi tidak signifikan. 
e. Pengujian hipotesis kelima, dengan menggunakan pendekatan fixed effect, diperoleh hasil bahwa growth opportunities mampu memoderasi pengaruh debt maturity terhadap keputusan investasi.

\section{DAFTAR PUSTAKA}

Aivazian, V.A., Ge, Y., Qiu, J., (2005), "The Impact of Leverage on Firm Investment: Canadian Evidence", Journal of Corporate Finance, 11, pp. 277-291.

Aivazian, V.A., Ge, Y., Qiu, J., (2005), "Debt Maturity Structure and Firm Investment", Financial Management, 34, pp. 107-119.

Barclay, M.J., Marx, L.M., dan Smith, C.W. 2001. The joint determinant of leverage and maturity, Working Paper: 2-27.

Bestari, Handayani. (2005). Pengaruh Struktur Modal Terhadap Nilai Perusahaan pada Pertumbuhan Perusahaan yang Berbeda. Tesis. UGM.

Billett, et al. (2007). Growth Opportunities and The Choice of leverage, Debt Maturity, and Covenants. The Journal of Finance Vol. LXII, No. 2 April 2007.

Dang, V.A. (2011). Leverage, Debt Maturity and Firm Investment: An Empirical Analysis. Journal of Business Finance \& Accounting; Jan-Mar 2011, Vol. 38 Issue 1/2, p225-258,

Jensen, M.C., (1986). Agency cost of free cash flow, corporate finance, and takeovers. American Economic Review. 76, 323-329.

Jensen, M., dan W. Meckling. (1976). Theory of The Firm: Managerial behavior, Agency Costs and Ownership Structure. Journal of Financial Economics 3, 305-360.

Johnson, Shane A. (2003). Debt Maturity and The Effects of growth Opportunities and Liquidity Risk on Leverage. Review of Financial Studies 16, 209236.

Lang, L.H.P., Ofek, E., Stulz, R.M. (1996). Leverage, Investment, and Firm Growth. Journal of Financial Economics 40, 3-29.

Lestari, Holydia. (2004). Pengaruh Kebijakan Utang, Kebijakan Dividen, Risiko dan Profitabilitas Perusahaan terhadap Set Kesempatan Investasi. 
Simposium Nasional Akuntansi VII. Ikatan Akuntansi Indonesia, Denpasar Bali 2-3 Desember, 1059-1070.

McConnell. J.J., dan Servaes, H. (1995). Equity Ownership and The Two Faces of Debt. Journal of Financial Economics 39, 131-157.

Meggison, W.L. (1997). Corporate Financial Theory. Massachusetts: Addison Wesley Educational Publishers.

Myers, S.C. (1977). Determinant of Corporate Borrowing. Journal of Financial Economics, 5: 147-175.

Myers, S.C. (2001). Capital Structure. Journal of Economic Perspectives, 15, pp. 81-102.

Stulz R.M., (1990), "Managerial Discretion and Optimal Financing Policies", Journal of Financial Economics, 26, pp. 3-27. 